\title{
Morpho-Productive and Chemical Composition of Local and Foreign Sweet Corn Hybrids Grown in the Conditions of Transylvania Plateau
}

\author{
Luana PĂCURAR ${ }^{1}$, Maria APAHIDEAN ${ }^{2}$, Voichița HAȘ ${ }^{1}$, Alexandru Ioan APAHIDEAN²* \\ ${ }^{1}$ Agricultural Research Center Turda (SCDA), 27 Agriculturii St., Turda, Romania \\ ${ }^{2}$ Department of Horticulture, University of Agricultural Sciences And Veterinary Medicine, \\ ${ }^{3}$ Mănăștur St., Cluj-Napoca, Romania \\ *Corresponding author, e-mail: alexandru.apahidean@usamvcluj.ro
}

Bulletin UASVM Horticulture 74(2)/ 2017

Print ISSN 1843-5254, Electronic ISSN 1843-5394

DOI:10.15835/buasvmcn-hort: 0016

\begin{abstract}
Sweet corn (Zea mays L.) belongs to the Gramineae family, var. rugosa (Bonof) convar. Saccharate (Sturt.) and can be distinguished from normal corn by presence of one or more mutant genes that affect carbohydrate metabolism in endosperm. Purpose of this research is to compare behavior of sweet corn hybrids created at SCDA Turda, but also foreign hybrids, in terms of quality elements and chemical composition, in conditions of Transylvania plateau, in two localities: Turda and Viişoara. As biological material following domestic sweet corn hybrids were chosen: 'Prima', 'Estival', 'Deliciul verii', 'Dulcin', 'Delicios', 'Estival M' and foreign hybrid 'Jubilee'. These hybrids were also analyzed in terms of chemical composition. Weight of 'Estival' hybrid has the best behavior in both localities; as regards to cobs length, 'Delicios' hybrid has registered increases very significant positive, differences between plant height in the two localities confirm significant influence of environment on formation of this important typical qualitative characteristics, highest performances in terms of $\beta$-cryptoxanthin and zeaxanthin content, are recorded by 'Jubilee' in both localities, 'Deliciul Verii' hybrid records significant value for lutein content, also recording an important addition of carbohydrates in Turda, 'Prima' and 'Estival' hybrids recorded highest values of sucrose in both localities.
\end{abstract}

Keywords: sweet corn, $\beta$-cryptoxanthin, zeaxanthin, lutein, sucrose

\section{INTRODUCTION}

Sweet corn is one of the most popular cultures, as its grains contain a number of nutrients indispensable to the human body.

It is grown for its milky grains, when it contains the most tasting qualities, and when nourishing substances are best assimilated by the body (Apahidean and Apahidean, 2001).

Taste and grains consistency depend on the content of soluble carbohydrates, the more they predominate, the more sweet the corn is. As corn advances towards physiological maturity, starch content increases, grain shell becomes hard and the taste quality decreases, which is why it is not advisable to delay its harvesting for consumption.
At the technological maturity, grains contain $25-27 \%$ dry matter, $14-15 \%$ carbohydrates, $5-5.5 \%$ proteins, $0.75 \%$ fats, amino acids: tryptophan and lysine. For $100 \mathrm{~g}$ of fresh product, they also contain vitamins: C-6.5 mg, B1- $0.4 \mathrm{mg}$, B2- $0.08 \mathrm{mg}, \mathrm{B} 6-3.8 \mathrm{mg}$, PP- $1.2 \mathrm{mg}$, E-1.3mg, and mineral elements: K-311 mg, P-125 mg, Ca-19 mg, $\mathrm{Mg}-117 \mathrm{mg}, \mathrm{Fe}-7 \mathrm{mg}$, and an energetic value of $370 \mathrm{~kJ}$ (Bojurian and Ţurcan, 1980 cited by Stan, 2001).

Lower temperatures $\left(18-20^{\circ} \mathrm{C}\right)$ during JuneAugust and normal precipitations positively influence the accumulation of carotenoid pigments.

Other nutritional properties of sweet corn are the important contribution of phytonutrients, such 
Tab. 1. Analysis of variants for corn cob weight at seven hybrids studied inTurda and Viişoara (2016)

\begin{tabular}{cccccc}
\hline \multirow{2}{*}{$\begin{array}{c}\text { Variability } \\
\text { Source }\end{array}$} & GL & \multicolumn{4}{c}{ Corn cob weight (g) } \\
\cline { 2 - 6 } & & \multicolumn{2}{c}{ With Husk } & \multicolumn{2}{c}{ Without Husk } \\
\cline { 2 - 6 } & & $\mathrm{s}^{2}$ & Probe & $\mathrm{s}^{2}$ & Probe \\
\hline Total & 39 & 9932 & & & \\
\hline Localities & 1 & 3043 & 4.80 & 769 & 3.17 \\
\hline Error (L) & 2 & 634 & & 243 & \\
\hline Hybrids (H) & 6 & 1596 & 0.78 & 3184 & $9.71^{* * *}$ \\
\hline Lx H & 6 & 2610 & 1.27 & 341 & 1.04 \\
\hline Error (H) & 24 & 2049 & & 1559 & \\
\hline
\end{tabular}

as carotene, lutein or cryptoxanthin. For example, zeaxanthin found in mature maize grains is also used as feed additive in poultry feed (intensifies the yellow color of egg yolk and their skin), pigs and fish (www.horticultura-bucuresti.ro).

Carotenoids are yellow, red or orange pigments that are spread both in the plant kingdom and in the animal kingdom. They accompany the green chlorophyll of the leaves and herbs of the plant kingdom and are present in many flowers, fruits, seeds or roots. They are synthesized only in the plant body and in the animal body are introduced with food.

About 600 carotenoids are known, of which the most common is $\beta$-carotene, the orange carrot pigment. In natural materials, carotenoids appear in smaller concentrations (less than $0.1 \%$ in carrot). They are easily oxidized. Their separation is relatively hard, in most cases being done by the chromatographic method. Most common are $\alpha$ - and $\beta$ - carotene, cryptoxanthin, zeaxanthin, lycopene, lutein.

Improvement of sugar maize began in Turda in 1971, when the first works that were based on the infusion of the recessive gene "su- 1 " were initiated on valuable inbred lines of normal type. As a result, in 1988 the 'Dulcin' tri-linear hybrid is homologated, followed three years later by the simple 'Prima' hybrid, which was considered the earliest of sweet corn hybrids experienced in the CSIOS network (Căbulea et al. 1994). In the years 2002 and 2004, two other hybrids were homologated, 'Estival' respectively 'Deliciul Verii'.

\section{MATERIALS AND METHODS}

The experience was set up in two locations, being a bifactorial experience of type A X G where factor A was represented by localities (Turda and Viişoara) and G factor of hybrids (the seven hybrids). Under the conditions of Viișoara, four waterings were applied starting from silkblooming phenophase. The variance appreciation was made using the Polifact program for the seven hybrids, of which six were native, namely 'Prima', 'Estival', 'Deliciul Verii', 'Dulcin', 'Delicios', 'Estival $\mathrm{M}$ ' and the foreign hybrid 'Jubilee'.

This experience was set up to bring some additional information on the behavior of the hybrids of corn hybrids created at Turda and foreign hybrids in the conditions in the center of Transylvania. Hybrids have been tested in terms of production components, morphological and qualitative (carotenoid, carbohydrate and sucrose content). In order to achieve the proposed objectives for improving the cultivation of sweet corn through the content of chemicals, analyzes of the carotenoid content of corn grains and quality control were carried out by NIR spectophotometry.

\section{RESULTS AND DISCUSSIONS}

Corn cob weight does not show significant differences under the factors influence. The lack of significance for the localities is due to the fact that in 2016 during the vegetation period of the maize were recorded significant amounts of rainfall, otherwise the year 2016 is considered rainiest year in Turda in the last 59 years. This could be the explanation for the lack of meanings between localities even if four waterings were started at Viişoara starting with silk-phenophase.

Due to the special conditions of 2016 and as it can be deduced from previous statements, the weight of cobs without husk has not registered 


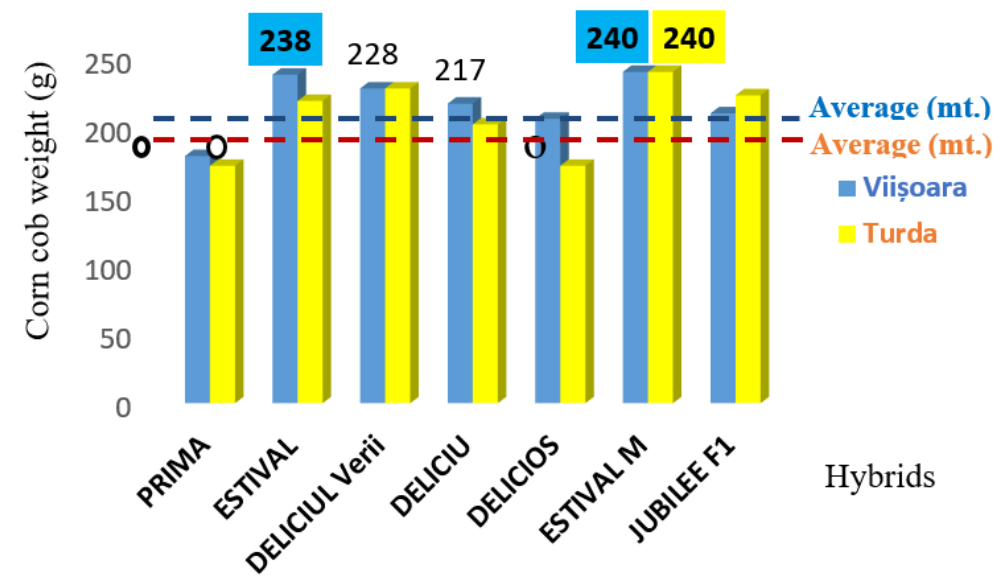

Fig. 1. Husk free corn cob weight in the studied hybrids (2016)

Tab. 2. Variant analysis for corn cob length at the seven hybrids studied in Turda and Viişoara (2016)

\begin{tabular}{cccccc}
\hline \multirow{2}{*}{$\begin{array}{c}\text { Variability } \\
\text { Source }\end{array}$} & GL & \multicolumn{4}{c}{ Corn cob lenght (cm) } \\
\cline { 3 - 6 } & & \multicolumn{2}{c}{ With husk } & \multicolumn{2}{c}{ Without husk } \\
\cline { 2 - 6 } & 39 & $\mathrm{~s}^{2}$ & Probe F & $\mathrm{s}^{2}$ & Probe F \\
\hline Total & 1 & 6 & $219.12^{* * *}$ & 4.52 & 4.06 \\
\hline Localities & 2 & 0.03 & & 1.11 & \\
\hline Error (L) & 6 & 7.96 & $10.37^{* * *}$ & 21.84 & $52.63^{* * *}$ \\
\hline Hybrids (H) & 6 & 2.25 & $2.93^{*}$ & 1.62 & $3.92^{* * *}$ \\
\hline Lx H & 24 & 0.77 & & 0.41 & \\
\hline Error (H) & 24 & & &
\end{tabular}

significant differences in the two localities. Results can be seen in figure 1 .

As you can see, among the seven hybrids studied, the lowest values of the weight of corn cobs are recorded at the first hybrid (Tab. 1), having both significantly different differences compared to the witness represented by the average of the experience. Also Delicios hybrid recorded a regression with statistically insured values, significantly negative but only in conditions from Turda compared to the witness. It seems that this hybrid reacted most favorably to the irrigation conditions in Viișoara, differences regarding weight of corn cobs between the two localities being the highest. Estival hybrid has the best behavior in both localities, even showing significant increases over the witness in Turda conditions. There are no significant differences between the weights of husk free cobs at the seven hybrids in the two localities, but still four from seven hybrids have higher values in the conditions of Viişoara compared to Turda.

Another important component of production is the length of corn cobs, the variance of which is shown in table 2. In sweet corn production, an important aspect is also the degree of cob cover form the husks, to increase the retention time in fresh form. From the data presented in table 2 it can be observed the very significant influence of the locality factor on the length of corn cobs with husk, which suggests the positive influence of the irrigations on the development of husks in terms of their length (Tab. 2). The abundance of precipitation in 2016 makes the influence of the localities factor insignificant as in the case of huskless corn cobs. As expected, the influence of the genotype factor on the length of corn cobs is very significant in both measurements. Significance is recorded even in the case of double factor interaction. 


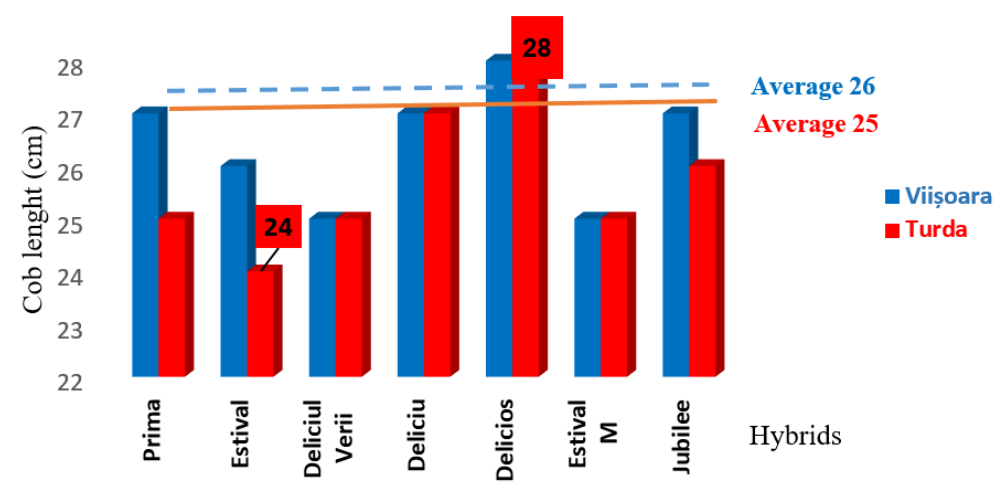

Fig. 2. The length of corn cobs of the seven hybrids in Turda and Viişoara (2016)

Tab. 3. Analysis of variance for plant height in the two localities, Turda and Viişoara (2016)

\begin{tabular}{ccccc}
\hline No. & $\begin{array}{c}\text { Variability } \\
\text { Source }\end{array}$ & GL & s $^{2}$ & Probe \\
\hline 1. & Localities & $\mathbf{1}$ & 7716.73 & $190.18^{* * *}$ \\
\hline 2. & Error (L) & 2 & 40.58 & \\
\hline 3. & Hybrids (H) & 6 & 1554.56 & $58.65^{* * *}$ \\
\hline 4. & L x H & 6 & 63.24 & 2.386 \\
\hline 5. & Error (H) & 24 & 26.51 & \\
\hline
\end{tabular}

Tab. 4. Chemical composition of seven hybrids in Turda (2016)

\begin{tabular}{ccccccc}
\hline Hybrid & $\begin{array}{c}\text { Lutein } \\
(\mu \mathrm{g} / 100 \mathrm{~g})\end{array}$ & $\begin{array}{c}\text { Zeaxanthin } \\
(\mu \mathrm{g} / 100 \mathrm{~g})\end{array}$ & $\begin{array}{c}\beta \text {-cryptoxanthin } \\
(\mu \mathrm{g} / 100 \mathrm{~g})\end{array}$ & $\begin{array}{c}\beta \text {-carotene } \\
(\mu \mathrm{g} / 100 \mathrm{~g})\end{array}$ & $\begin{array}{c}\text { Total } \\
\text { carotenoids } \\
(\mu \mathrm{g} / 100 \mathrm{~g})\end{array}$ & $\begin{array}{c}\text { Dry substance } \\
\%\end{array}$ \\
\hline Prima & 2.36 & 2.68 & 0.93 & 0.23 & 6.64 & 24 \\
\hline Estival & 4.41 & 1.54 & 1.51 & 0.00 & 7.97 & 22 \\
\hline Deliciul Verii & 7.33 & 2.24 & 1.82 & 0.00 & 11.90 & 31 \\
\hline Deliciu & 3.24 & 1.24 & 1.00 & 0.14 & 5.55 & 27 \\
\hline Delicios & 4.99 & 2.19 & 1.29 & 0.28 & 9.46 & 30 \\
\hline Estival M & 3.98 & 1.91 & 1.38 & 0.00 & 8.90 & 31 \\
\hline Jubilee & 3.55 & 2.19 & 1.90 & 0.66 & 9.36 & 25 \\
\hline
\end{tabular}

As for the length of the cobs, Delicios hybrid registered very significant positive gains, and the lowest performances belonged to Estival hybrid with distinctly negative differences both in Turda conditions (Fig. 2). It can be seen that some hybrids behaved similarly in the two systems of culture, and the difference between the averages in the two localities is practically very small by only $1 \mathrm{~cm}$.

The influence of the two localities and hybrids on plants height is very significant, indicating on one hand the important involvement of the genotype in the control of this typical quantitative characteristic and also the important role of the environment in the phenotypic expression of the plant's height (Tab. 3).

Hybrids were also analyzed for the chemical composition shown in tables 4 and 5 . As can be seen, $\beta$-carotene content of the seven maize hybrids in the two localities varies between 0 and $1 \mathrm{mg} / 100 \mathrm{~g}$. Following analyzes carried out on maize hybrids: Estival, and Deliciul verii, $\beta$ carotene could not be identified for the samples from both localities and at Estival M for the locality Turda.

Another important pigment is zeaxanthin which was between 1.24 and $2.99 \mathrm{mg} / 100 \mathrm{~g}$, so 
Tab. 5. Chemical composition of seven hybrids in Viisoara (2016)

\begin{tabular}{|c|c|c|c|c|c|c|}
\hline Hybrid & $\begin{array}{c}\text { Lutein } \\
(\mu \mathrm{g} / 100 \mathrm{~g})\end{array}$ & $\begin{array}{l}\text { Zeaxanthin } \\
(\mu \mathrm{g} / 100 \mathrm{~g})\end{array}$ & $\begin{array}{c}\beta \text {-cryptoxanthin } \\
(\mu \mathrm{g} / 100 \mathrm{~g})\end{array}$ & $\begin{array}{l}\beta \text {-carotene } \\
(\mu \mathrm{g} / 100 \mathrm{~g})\end{array}$ & $\begin{array}{c}\text { Total } \\
\text { carotenoids } \\
(\mu \mathrm{g} / 100 \mathrm{~g})\end{array}$ & $\begin{array}{c}\text { Dry substance } \\
\%\end{array}$ \\
\hline Prima & 2.34 & 2.63 & 0.83 & 0.23 & 7.00 & 23 \\
\hline Estival & 4.37 & 1.68 & 1.11 & 0.00 & 8.08 & 32 \\
\hline Deliciul Verii & 3.97 & 1.59 & 1.11 & 0.00 & 7.23 & 31 \\
\hline Deliciu & 4.97 & 2.99 & 1.23 & 0.00 & 10.22 & 31 \\
\hline Delicios & 4.76 & 2.83 & 1.70 & 0.21 & 10.17 & 29 \\
\hline Estival M & 5.50 & 2.72 & 1.71 & 0.16 & 12.00 & 33 \\
\hline Jubilee & 5.03 & 3.29 & 2.44 & 1.00 & 12.99 & 30 \\
\hline & 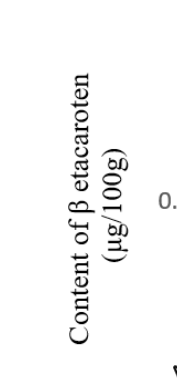 & & & & $\begin{array}{l}\text { - Viișoara } \\
\text { = Turda }\end{array}$ & \\
\hline
\end{tabular}

Fig. 3. $\beta$-carotene content of the seven hybrids in the two localities

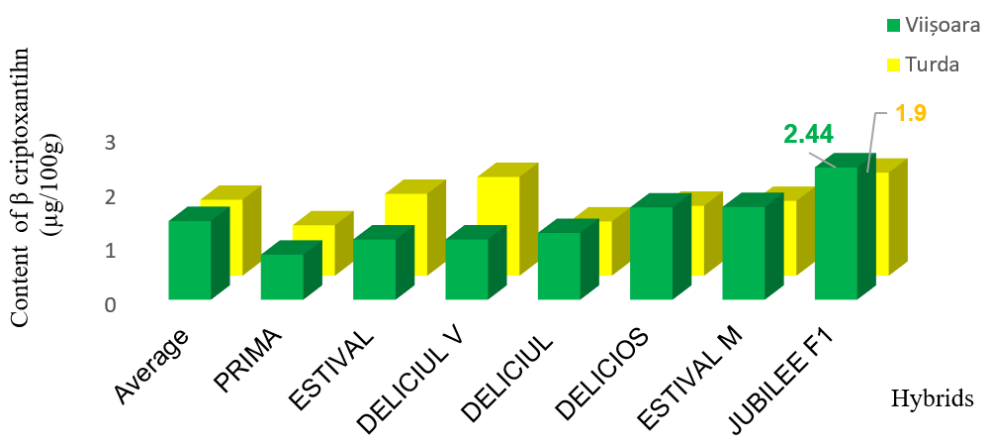

Fig. 4. $\beta$-cryptoxanthin content of the seven hybrids in the two localities

hybrid Prima, although less productive, seems to excel in this aspect (Tab. 4 and 5).

From the point of view of the total carotenoid content, one can notice an important fluctuation of the seven hybrids between 5.5 and $12.99 \mathrm{mg} /$ $100 \mathrm{~g}$, as well as the influence of the watering on the carotenoids, thus in the conditions of Viişoara being recorded an important increase in total carotenoids.

Of the analyzed hybrids, Jubilee achieved the highest $\beta$-carotene content of 1 and $0.66 \mu \mathrm{g} / 100$ g respectively (Fig. 3 ). Content of $\beta$-carotene in the corn is rather low and there are even some hybrids to which it was not reported.

In a study of two varieties of corn, one with white and one with golden-yellow grains (Scott and Eldridge 2005) identified in the first varieties a content of $0.82 \mu \mathrm{g} / 100 \mathrm{~g} \beta$-caroten and $15.69 \mu \mathrm{g} / 100 \mathrm{~g}$ for the second varieties. The two performed several determinations starting with milk baking phenophase every five days and found that the carotenoid content values did not change.

The highest performances in terms of $\beta$ cryptoxanthin content are recorded at Jubilee 


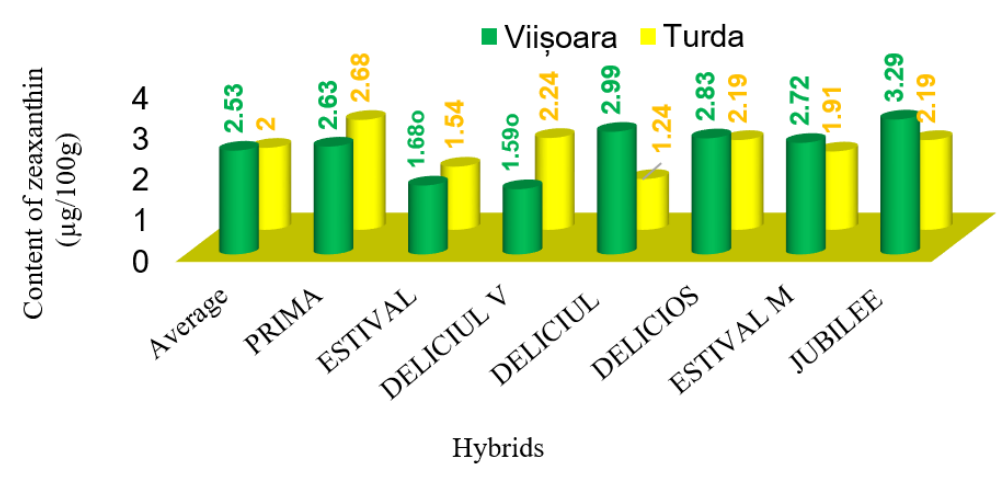

Fig. 5. Hybrids content of zeaxanthin

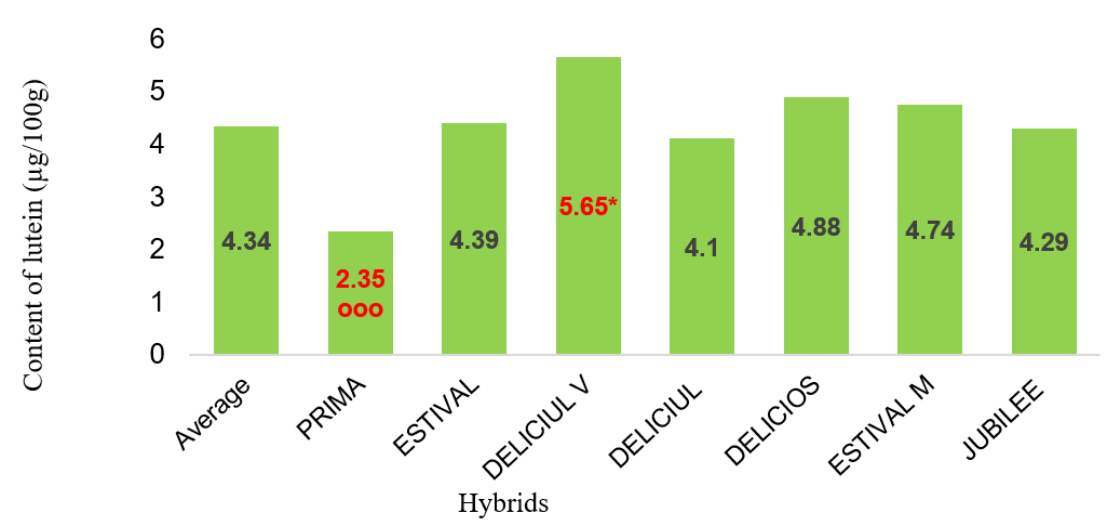

Fig. 6. Average content of lutein, in the two localities Turda and Viişoara at studied hybrids (2016)

hybrid in both localities, registering very significant and significantly positive gains compared to the average. The reaction of the other hybrids is quite similar in both localities, with the exception of the Estival hybrids and Deliciul verii which have achieved superior values of $\beta$ - cryptoxanthin content in Turda (Fig. 4). Different values of $\beta$-cryptoxanthin were reported in the study by (Scott and Eldridge 2005), varying according to the analyzed corn variety, namely $0.4 \mu \mathrm{g} / 100 \mathrm{~g}$ of fresh grains with white grains and $31.6 \mu \mathrm{g} / 100 \mathrm{~g}$ in the golden-yellow grains forms. Values found in this study are above the values recorded by (Scott and Eldridge 2005) in the corn forms with white grains and below those identified in the one with the golden yellow grains.

Beta cryptoxanthin is a carotenoid similar to $\beta$-carotene being pro-vitamin $\mathrm{A}$, it is also an effective antioxidant reducing the effects of oxidative stress on the body. Antioxidant nature can prevent various diseases such as cardiovascular disease.

Graphical representation regarding behavior of the seven hybrids in the zeaxanthin content is shown in figure 5. Most hybrids recorded higher values of zexanthin content in Viişoara, the lowest values being attributed to the Estival and Deliciul verii hybrids which recorded significant decreases of zeaxanthin compared to average. Group leader is Jubilee hybrid which records an average of 2.74 $\mu \mathrm{g} / 100 \mathrm{~g}$ of zeaxanthin in the two localities, followed by Prima hybrid with $2.65 \mu \mathrm{g} / 100 \mathrm{~g}$.

Zeaxanthin is found in the most important source: corn, egg yolk, yellow pepper and leek. Zeaxanthin and lutein are the only carotenoids found in the retina and the lens, many studies have been done to determine their effects on the eyes, finding that a diet rich in zeaxanthin and lutein may slow vision degradation, and can prevent cataracts (Http://cesamancam.ro/luteinazeaxantina.html).

As previously stated, the localities have not influenced lutein content so figure 6 shows the average content of lutein in the two localities. Leader of the group in terms of lutein content is 'Deliciul verii', and at the opposite end is 'Prima' with a significantly negative lutein content 


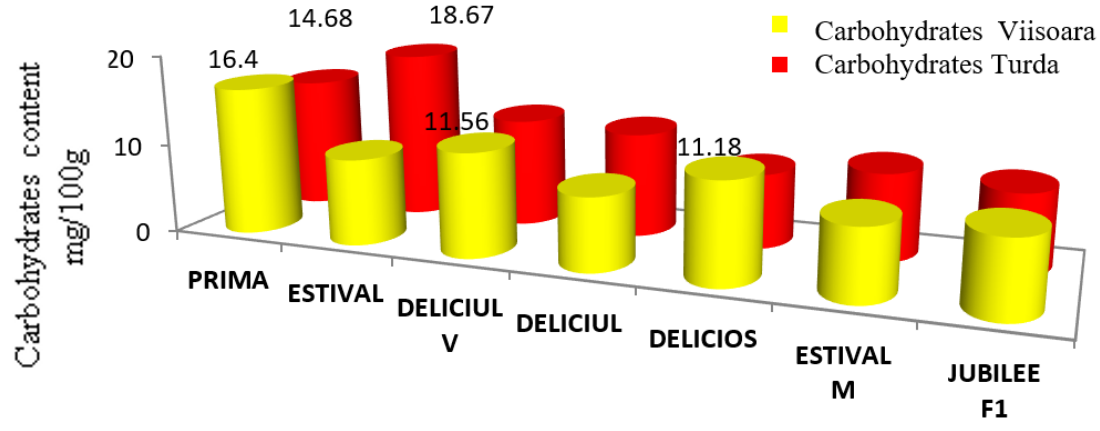

Fig. 7. Content of carbohydrates in the seven hybrids in Turda and Viişoara (2016)

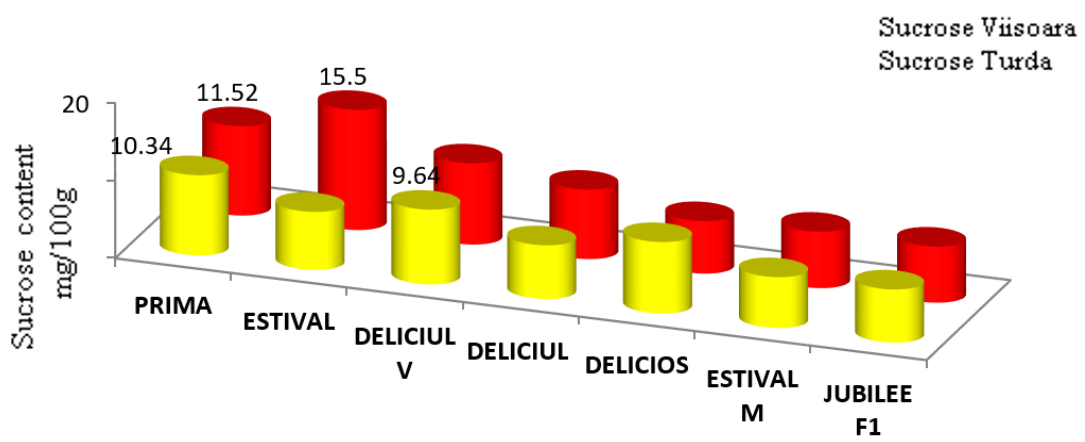

Fig. 8. Sucrose content in the seven hybrids in Turda and Viişoara (2016)

compared to control. In other, the lutein content varies between 4.1 and $4.88 \mu \mathrm{g} / 100 \mathrm{~g}$.

Content of carbohydrates at the sweet corn hybrids was more favorable under the conditions of Turda compared to Viişoara (Fig. 7). 'Prima' had a higher content of carbohydrates in the two localities of $16.4 \mathrm{mg} / 100 \mathrm{~g}$ and $14.68 \mathrm{mg}$ $/ 100 \mathrm{~g}$, respectively. 'Estival' hybrid showed some degree of instability in the carbohydrate content. Differences between the two localities are obvious in terms of this attribute.

The other hybrids presented lower gluten content and quite close in both localities except hybrid 'Deliciul verii', which recorded the highest content of gluten in Turda.

Sucrose content of the seven hybrids is similar to the appearance of carbohydrates, 'Prima' having the highest values of this taste quality in both localities. 'Estival' recorded the highest values of $15.5 \mathrm{mg} / 100 \mathrm{~g}$ of sucrose under the conditions of Turda (Fig. 8).

\section{CONCLUSIONS}

A good behavior with regard to weight of husk-less corn cobs can be attributed to 'Estival' in both localities;
In regard of cobs length, 'Delicios' which registered very significant positive gains compared to the average of other hybrids;

Differences between plant height averages in the two localities confirm the major role of the environment in the phenotypic expression of this important quantitative characteristic;

The highest performances in terms of $\beta$-cryptoxanthin and zeaxanthin content are recorded by 'Jubilee' in both localities;

'Deliciul verii' records a significant value in the content of lutein, as well as an important plus of carbohydrates in Turda;

'Prima' and 'Estival' are the most performing of thesevenhybrids analyzed in terms of carbohydrate content and implicitly sucrose content in both localities, suggesting an important involvement of the genotype in the two components.

\section{REFERENCES}

1. Apahidean AlS, Apahidean, M (2001). Legumicultură specială. Ed. Academic Press., Cluj-Napoca

2. Cabulea I, Haș V, Grecu C, Haș I (1994). Hibrizii de porumb cu bobul zaharat creati la Statiunea de Cercetari Agricole Turda. Cereale si plante tehnice 6-7: 22-24.

3. Stan N (2001). Legumicultură. Vol. II. Editura Ion Ionescu de la Brad, Iaşi 
4. Săvulescu TR, Zaharidi C (1957). Monografia, anatomia şi sistematica porumbului. Porumbul studiu monographic. Ed.Tr. Săvulescu. Acad. de Şt.,București, 74-137.

5. Scott EC, Eldridge AL (2005). Comparison of carotenoid content in fresh, frozen and canned corn. Journal of Food Composition and Analysis 18: 551-559.
6. ***http://www.horticultura- bucuresti.ro
7. ${ }^{* * *}$ http://cesamancam.ro/beta-criptoxantina.html
8. **http://cesamancam.ro/luteina-zeaxantina.html 